\title{
Exploring the Rationale for Assuring Integrated Reports and its Impacts on Assurance Practices: A Proposed Conceptual Model
}

\author{
${ }^{1}$ Herath R., ${ }^{2}$ Senaratne S., ${ }^{3}$ Gunarathne N. \\ ${ }^{1,2,3}$ Department of Accounting, University of Sri Jayewardenepura, Sri Lanka \\ ${ }^{1}$ roshanherath@sjp.ac.lk, ${ }^{2}$ samanthisenaratne@sjp.ac.lk, ${ }^{3}$ nuwan@sjp.ac.lk
}

\begin{abstract}
There is a growing demand for external assurance on integrated reporting despite the challenges involved in the assurance process. However, the rationale for obtaining external assurance on integrated reports is mostly unknown, and how it leads to organisational changes is not sufficiently explored. Thus, this study offers a conceptual model to explore the rationale behind obtaining external assurance on integrated reporting, its impacts on internal assurance practices, justifications for modifications made to the internal assurance practices, and its implications on external assurance practices. This conceptual model, grounded on the framing and institutional theories, postulates that companies tend to assure their integrated reports externally as a response to various isomorphic pressures. The external assurance of an integrated report may warrant modifications to companies' current internal assurance practices. Companies make these modifications based on different rationales, which can also have implications on external assurance practices. This paper also discusses how researchers and practitioners can use this model.
\end{abstract}

Keywords: external assurance, framing theory, institutional theory, integrated reporting, internal assurance

\section{Introduction}

There is a growing global trend for companies to adopt new corporate reporting models such as integrated reporting (IR) (Cooray et al., 2021), which provides a forward-looking assessment of an entity's value creation process through its multidimensional six capitals that entail financial and non-financial information. However, this forward-looking assessment of value creation and the consideration of multidimensional aspects, covering both financial and non-financial information, brings some subjectivity into IR. Although this subjectivity makes the assurance of an integrated report challenging (Maroun, 2019), growing demand for external assurance on the integrated report has been witnessed globally (Maroun, 2019; KPMG, 2017; International Integrated Reporting Council (IIRC), 2014). Despite the IR assurance practice developments, only a limited number of studies have been conducted so far. For instance, these studies have explored limited areas such as challenges in the assurance process (Cheng et al., 2014; Huggins et al., 2015; Simnett \& Higgins, 2015; Stubbs \& Huggins, 2014), motives for assurance (Briem $\&$ Wald, 2018; Maroun, 2019), the role of external assurance providers (Briem \& Wald, 2018), and changes required to current external assurance practices (Maroun, 2019). Therefore, scholars have emphasised the need to explore how and why 
companies choose to get the integrated reports assured and how the assurance process leads to organisational changes (de Villiers et al., 2017; Rinaldi et al., 2018).

The failure to reveal how the external assurance of IR leads to organisational changes could undermine the potential of external assurance on IR. This is a significant matter to consider as the external IR assurance processes can enhance report quality and provide more reliable disclosures on non-financial information (Briem \& Wald, 2018; Maroun, 2019; PwC, 2015; Zhou et al., 2017). In addition to these benefits related to reporting, external IR assurance can also lead to better coordination between the different parts of the organisation and ensure sound decision-making due to the availability of financial and non-financial information through the improved systems. Further, the external IR assurance would lead to improvements in the internal control systems, resulting in better control over resources and efficient employee engagement (Briem \& Wald, 2018; Maroun, 2019). Hence, in the absence of studies to expose the implications of external IR assurance on internal assurance practices (including internal controls and systems), organisations would fail to realise these benefits of external IR assurance. The review of the extant literature on external IR assurance revealed a dearth of studies on the implications of external IR assurance on internal assurance practices.

This study thus aims to offer a conceptual model to explore the following:

a) the rationale behind obtaining external IR assurance;

b) the impact of external IR assurance on internal assurance practices;

c) the justification for modifications made to the internal assurance practices; and

d) the implications for external assurance practices.

In developing this conceptual model, this study uses the institutional theory and the framing theory concurrently. More specifically, this study uses the framing theory as a broad framework for identifying problems (i.e., the rationale behind obtaining external IR assurance), proposing remedies (impact of external assurance on internal assurance practices) and driving change (the justification for modifications made to the internal assurance practices and implications to the external assurance practices). In order to provide a deeper understanding of rationales (i.e., the rationale behind obtaining external IR assurance), institutional theory is utilised to complement the framing theory in this study.

This paper complements the work of Briem and Wald (2018) and Maroun (2019) on external assurance on IR. Briem and Wald (2018) first examined what factors motivate companies to have their integrated reports externally assured. They drew on institutional and diffusion-of-innovations theories to identify the coercive pressure driving the decision to have integrated reports assured as well as the external auditor's role in the assurance process. Maroun (2019), based on the framing theory, provided a more structured account of the motivation behind obtaining external assurance on IR. Further, he focused on the implications of IR assurance to the external-assurance practices and proposed some modifications to such practices with a rationale. The present study extends the work of Maroun 
(2019) in two ways. First, it broadens the rationale for IR assurance by introducing competitive isomorphic pressures to complement institutional isomorphic pressures. Hence, this study argues that the assurance of IR may not be merely an exercise for seeking legitimacy; instead, it may also be a result of seeking efficiency, given the novelty of IR assurance practice. Second, this study also focuses on the implication of external IR assurance on internal-assurance practices and the justification for the changes made, specifically to these practices as well as implications for externalassurance practices. Accordingly, this study proposes a framework for both academics and practitioners (e.g., policymakers, preparers and users of integrated reports) to apply external- and internal-assurance practices on IR.

The rest of the paper is organised as follows: Section Two provides the literature review while Section Three describes the theoretical frameworks relevant to the study. Section Four presents the model development, followed by future directions and applications.

\section{Literature Review}

This section first presents the literature to explain the concepts of IR and assurance in general and thereafter discusses empirical studies on the assurance on IR.

\section{The Concept of Integrated Reporting (IR)}

IR entails a new and innovative approach to current corporate reporting practices (Adams \& Simnett, 2011; Nicolo et al., 2020). It combines the most material financial and non-financial information currently reported in separate reporting strands into a coherent whole (i.e., through an integrated report) and explains how they affect the ability of an organisation to create and sustain value in the short, medium, and long terms (Cooray et al., 2020; IIRC, 2011; Tlili et al., 2019). Thus, IR aims to develop a holistic corporate-reporting model (Camodeca et al., 2018; Eccles \& Krzus, 2010) which depicts inter-connectivity between a firm's strategies and performance and the economic, social and environmental contexts within which it operates. According to Simnett and Huggins (2015), the development of IR has not been straightforward; IR is probably one of the most disruptive innovations in the field of corporate reporting. In this respect, Dragu and Tudor-Tiron (2013) state that three factors have contributed to the revolution of IR that commenced in 2010: i.e., non-financial reporting initiatives, reporting of sustainable practices and integrated thinking.

The outcome of IR is the integrated report, which entails an innovative approach to current corporate reporting practices (Adams \& Simnett, 2011). The IIRC (2013, p. 07) defines an integrated report as "a concise communication about how an organisation's strategy, governance, performance, and prospects, in the context of its external environment, lead to the creation of value over the short, medium and long term." Over a short period, IR has gained global popularity because of its potential to change the corporate decision maker's mindset, which can further strengthen the sustainability actions and impact of the organisational strategicplanning process, decision-making, and performance measurement systems (Adams, 2015: Robertson \& Samy, 2015). Thus, the preparation of an integrated 
report has become an attractive reporting practice as it brings all the financial and non-financial information on multiple capitals together and enhances the integrated thinking' related to identifying material factors that have a significant influence on creating value over time (Du Toit, 2017; Herath, 2021). With the growing importance of IR, there is a call for these reports to be subject to external assurance or verification (IIRC, 2014). In this context, the concept of assurance is explored in the next section.

\section{Concept of Assurance}

The term 'assurance' is not explicitly defined. Instead, several explanations are available regarding what constitutes assurance, and they relate mainly to external assurance. The Global Reporting Initiative (GRI) (2020, p. 41) refers to external assurance as the "activities designed to result in published conclusions on the quality of the report and the information (whether it be qualitative or quantitative) contained within it." On the other hand, AA1000AS provides a more detailed definition of 'assurance,' describing it as 'the methods and processes employed by an assurance provider to evaluate an organisation's public disclosures about its performance as well as underlying data, processes and systems, against suitable criteria and standards to increase the credibility of public disclosure" (AccountAbility, 2018, p. 36). In common, these definitions emphasize that external assurance relates to the activities designed to result in published conclusions about the systems or processes of organisations.

Further, the International Framework for Assurance Engagements issued by the International Auditing and Assurance Standards Board (IAASB) of the International Federation of Accountants (IFAC) (2014) defines an assurance engagement as "an engagement in which a practitioner obtains sufficient appropriate evidence in order to express a conclusion designed to enhance the degree of confidence of the intended users other than the responsible party about the outcome of the measurement or evaluation of an underlying subject matter against criteria" (p. 13). This framework demarcates the assurance engagements broadly as 'reasonable assurance engagements ${ }^{1}$, and 'limited assurance engagements ${ }^{2}$ ' based on the level of assurance provided.

1 The objective of a reasonable assurance engagement "is a reduction in the assurance engagement risk to an acceptably low level in the circumstances of the engagement as the basis for a positive form of expression of the practitioner's conclusion" (International Framework for Assurance Engagements, 2014, P.13).

2 The objective of a limited assurance engagement "is a reduction in assurance engagement risk to a level that is acceptable in the circumstances of the engagement, but where that risk is greater than for a reasonable assurance engagement, as the basis for a negative form of expression of the practitioner's conclusion" (International Framework for Assurance Engagements, 2014, P.14). 
The level of assurance obtained by an organisation on its public disclosures is decided by the confidence level that external stakeholders or management demand (Deegan et al., 2006). The assurance engagement risk level is higher in a limitedassurance than in a reasonable-assurance engagement (IFAC, 2014). Further, assurance engagements can be undertaken on the various underlying subject matter, including financial and non-financial information. The reasonable-assurance engagement provided on historical financial information is termed as 'audit', carried out based on international auditing standards (IFAC, 2014). Conversely, a limitedassurance engagement on financial or non-financial information is termed as a 'review engagement.'

External assurance engagements on non-financial information are typically performed following ISAE 3000 (Assurance Engagements other than audits or reviews of historical financial information) or AA1000AS. The ISAE 3000 is a generic standard issued by the IAASB to guide professional accountants in public practice for the performance of assurance engagements other than those on historical financial-assurance engagements. It establishes the basic principles and essential procedures on the two levels of assurance engagements: reasonable and limited. On the other hand, AA1000AS issued by AccountAbility ${ }^{3}$ is a more specific sustainability assurance standard. It is the generally applicable standard for assessing, attesting to and strengthening the credibility and quality of an organisation's sustainability reporting, underlying processes, systems and competencies. Both ISAE and AA1000AS are designed to assure information that can be objectively tested according to clearly defined criteria.

However, the term 'assurance' broadly covers the services provided by independent third parties as well as internal sources of assurance such as the work of internal auditors, verifications by environmental, social and governance specialists, and monitoring by audit committees (Prinsloo \& Maroun, 2020). GRI (2020) states that an organisation can have internal control systems to improve the overall integrity and credibility of a report in addition to external assurance, which also includes establishing and maintaining an internal audit function as a part of organisational processes for risk management and for managing and reporting information. In this respect, Institute of Directors (IOD) (2016) opines that an organisation's governing body should ensure that, collectively, different sources of assurance would enable an effective controlled environment in an organisation that supports the integrity of information for the decision-making of both internal and external users. This would be of greater importance for the combined assurance approach in organisations that deal with different types of systems, processes and controls on which the governing body relies to discharge its fiduciary duties. The combined assurance model can be explained using the 'lines of defence' model adopted by the Institute of Internal Auditors (IIA) (2013) to distinguish among the three groups involved in risk management in an organisation. In this model, the first line refers to the functions

${ }^{3}$ AccountAbility is a UK-based global consulting and standards organization that works with multi-stakeholders on environmental, social and governance matters. 
that own and manage risks (operational management), the second line refers to the functions that oversee risks (risk management and compliance functions), and the third line refers to the functions that provide independent assurance (internal audit). Thus, PwC (2014) argues that combined assurance clarifies risks, considers their effect on the company's ability to meet its strategy and also protects or creates value by improving reporting, minimising operational disruptions and tracking remedial actions on the identified opportunities/threats.

The discussion carried out in this section shows that the assurance of corporate reports and the reporting process can be considered from a broad perspective. Accordingly, the next section reviews the current literature as to assurance on IR.

\section{Assurance on IR}

The developments in IR in the practitioner's sphere have also led to several studies covering some facets of IR assurance (Cheng et al., 2014; Dumay et al., 2016; Huggins et al., 2015; Stubbs \& Higgins, 2014; Simnett \& Huggins, 2015; Goicoechea et al., 2019; Briem \& Wald, 2018; Maroun, 2019). For instance, Huggins et al. (2015) stress the practical challenge of the applicability of conventional standards to assure an integrated report and the technical difficulties to assure future-oriented information. Cheng et al. (2014) question the relevance of IR assurance without knowing or understanding the underlying processes. Further, Stubbs and Huggins (2014) raise their concern over the IIRC framework's suitability as an assurance criterion. In another study, Simnett and Huggins (2015) emphasize the problem of requiring more sophisticated skills in the assurance companies and the change of mindset required in assuring an integrated report. Goicoechea et al. (2019) found that the users of IR, as well as auditors, perceive the assurance of IR to be essential. Still, there are many challenges (both methodological and non-financial information related) for auditors to overcome. More specifically, both groups considered auditing the content elements of "financial performance", "basis of preparation and presentation" and "governance" to be the most important. In contrast, "organisational overview and external environment", "non-financial performance" and "strategy and resource allocation" were considered the least important. This is primarily due to the awareness of users of IR and auditors of the difficulty associated with the assurance of each content element of an integrated report. Assurance of "organisational overview and external environment", "non-financial performance" and "strategy and resource allocation" is quite difficult compared to the assurance of "financial performance", "basis of preparation and presentation" and "governance."

On the other hand, Briem and Wald (2018) investigate the reasons for voluntarily obtaining external assurance on the integrated report and external auditors' role in Germany's assurance process, a context where IR's adoption is voluntary. They found that companies follow coercive pressures by their stakeholders when obtaining external assurance and that the appreciation of non-financial information is necessary for staying credible with their investors. Also, they perceive external assurance as further support for data quality. Further, they stress that the auditors play an important role as change agents for implementing IR assurance by 
supporting the correct interpretation of the IIRC definitions and by promoting IR. Similarly, Maroun (2019) explores the rationale for external assurance on the integrated report, changes required to existing assurance practices and motivation for proposed changes to existing practices. He found three broad views on assurance: expectation- management perspective, value-adding perspective and change-potential perspective. An expectation-management perspective holds that the integrated report must be assured to secure legitimacy by aligning with the generally accepted view that corporate reporting should be subject to at least some form of assurance. A value-adding perspective emphasizes the role of assurance in improving the quality of non-financial information reported to stakeholders and its function as part of a broader corporate governance system, especially the support extended to the internal auditors where the internal auditor lacks the resources, expertise, or independence to test the underlying data and systems. A changepotential perspective emphasizes that assurance enhances the change potential of IR by providing additional feedback on systems, processes and data as well as heightening the sense of accountability.

Both Briem and Wald (2018) and Maroun (2019) have acknowledged that external assurance feedback could improve companies' internal control systems. The improved internal control systems are particularly useful to enhance the credibility and reliability of non-financial disclosures (Jones \& Solomon, 2010; Simnett et al., 2009; Soh \& Martinov-Bennie, 2015). Thus, it increases the overall usefulness of an integrated report, adding value to the stakeholders (Briem \& Wald, 2018; Corrado et al., 2019; Maroun, 2019; PwC, 2015; Zhou et al., 2017). Further, the improved internal control systems could enhance organisational efficiency through better departmental coordination, effective human resources management, and improvements in non-financial data gathering. These improvements could better facilitate integrated decision making, eventually leading to greater value creation by an organisation (Briem \& Wald, 2018; Busco et al., 2013; IIRC, 2013; Integrated Reporting Committee of South Africa, 2014). However, the in-depth impact of external assurance of IR on current internal assurance practices (internal controls and systems), including the justification for such modification made to internal assurance practices despite the significance assigned to combined assurance practices on IR, have not yet been examined (Maroun, 2019; Prinsloo \& Maroun, 2020). This study, thus, develops a conceptual model to explore the rationale for assuring integrated reports and their impacts on assurance practices. The development of the conceptual model is presented in the next section.

\section{Theoretical Frameworks}

The study's approach to conceptual model development is based on two theories: framing theory and institutional theory. This section briefly presents these two theories, their relevance to this study and how they are used in developing the conceptual model.

The framing theory has been widely applied in social sciences when core framing tasks (diagnostic, prognostic and motivational) are used to explain how social movements identify problems, propose remedies and drive change (Benford \& 
Snow, 2000). The framing theory application offers a diagnostic framing to identify and define problems (Benford \& Snow, 2000). In social sciences, this is frequently described as a 'mode of interpretation' used to isolate a problematic situation, articulate its causes, assign blame, and suggest remedial actions (Snow et al., 1986). According to Roussy and Brivot (2016), the term 'diagnosis' refers to how a particular scenario is interpreted, how a task is understood or how an objective or goal should be determined and defined. Then, the prognostic framing proposes remedies (Benford \& Snow, 2000; Bay, 2011). Accordingly, in order to solve the problem, prognostic framing identifies appropriate strategies by assessing the relevant risks. Thus, prognostic framing adds an action-orientated element to a problem defined by diagnostic framing (Snow et al., 1986). Finally, motivational framing focuses on communicating the ideas generated by diagnostic and prognostic framing to encourage implementation (Bay, 2011). According to Benford and Snow (2000), motivational framing amounts to providing the rationale for collective action.

The framing theory has been successfully used in accounting settings to examine the development of specific environmental accounting practices (Ascui \& Lovell, 2011), different interpretations on internal audit quality (Roussy \& Brivot, 2016), how managers deal with uncertain business environments (Kaplan, 2008) and to explore the rationale for IR assurance (Maroun, 2019). Accordingly, in the current study, the framing theory is used to understand broadly why companies obtain external assurance on integrated reports, to identify the impact of external assurance on internal assurance practices and to explore the justification for modifications made to the internal assurance practices and its implications for external assurance practices.

However, the framing theory does not explicitly offer a theoretical background to analyse why companies adopt certain organisational practices (i.e., different factors driving the companies to obtain external assurance). Hence, this study incorporates the institutional theory to compliment the framing theory. The institutional theory provides a useful theoretical lens to discuss how an organisation's overall institutional environment influences organisational practices (DiMaggio \& Powell, 1983). More specifically, this theory has been previously used in accounting studies to explore the factors that influence various reporting and assurance practices (Briem \& Wald, 2018; Chen \& Bouvain, 2009; Fortanier et al., 2011; Lasmin 2011; Martínez-Ferrero \& García-Sánchez, 2017; Vaz et al., 2016).

The institutional theory explains why organisational structures and practices become more homogeneous and how and why such changes occur (DiMaggio \& Powell, 1983). The institutional view posits that organisation adopt uniform structures over time, a process called 'isomorphism'. This isomorphism can occur primarily due to two pressures: a) institutional and b) competitive. Institutional isomorphism holds that the adoption of a particular organisational system is driven primarily by the organisation's need to conform to external pressures to ensure legitimacy (Covaleski \& Dirsmith, 1988; DiMaggio \& Powell, 1983; Meyer \& Rowan, 1977; Moll et al., 2006). In contrast, its competitive viewpoint is that the adoption of a particular organisational system is driven mainly by the desire for 
increased internal efficiency (Etherington \& Richardson, 1994; Gonzalez et al., 2009; Tuttle \& Dillard, 2007).

According to DiMaggio and Powell (1983), institutional isomorphism can result from coercive, normative, and mimetic pressures. Coercive isomorphism refers to the formal or informal forces exerted by other entities upon which the organisation is dependent as well as cultural expectations in the society within which the organisation functions. For instance, external assurance of companies' integrated reports can be influenced by the coercive pressure of powerful stakeholder groups (Briem \& Wald, 2018). When the environment is surrounded by uncertainty, mimetic pressures can cause the organisation to imitate other successful organisational structures and practices. In situations where a straightforward course of action is unavailable, organisational leaders may decide that the best response is to mimic a peer that they perceive to be successful (Mizruci \& Fren, 1999). On the other hand, normative isomorphism stems from professionalisation. In other words, similar attitudes, behaviours and practices come into organisations whose members have the same educational background. Conversely, competitive isomorphism relates to the search for efficiency and is primarily relevant in situations where free and open competition exists (Oliver, 1991).

In a previous study that identifies the determinants of the voluntary assurance of sustainability reports, Martínez-Ferrero \& García-Sánchez (2017) found that context-specific factors, especially cultural and legal frameworks, affect the relative strength of coercive, normative and mimetic pressures. They further report that normative pressures are the strongest determinants of assurance of voluntary sustainability reports, followed by coercive and mimetic pressures. Vaz et al. (2016) analyse country-specific determinants of the use of IR from an institutional-theory perspective and find evidence for the influence of factors such as the national culture or the regulatory framework. Further, the institutional theory has been adopted to examine factors that influence countries to adopt international financial reporting standards (Lasmin, 2011) and as a framework for studying the convergence of corporate social responsibility reporting in several countries (Chen \& Bouvain, 2009; Fortanier et al., 2011).

Briem and Wald (2018) investigated the reasons for voluntarily obtaining IR assurance using the institutional theory and found that the companies follow coercive pressures from their stakeholders when obtaining external assurance. The companies also consider the appreciation of non-financial information necessary for staying credible with their investors. Further, they perceive external assurance as additional support for enhancing data quality. When all these studies are considered, it is clear that all have solely focused on institutional isomorphism. None of these studies has considered competitive isomorphism to explain the homogeneity of accounting practices. This finding implies that the researchers who have used the institutional theory in their studies predominantly take the view that the adoption of a particular organisational system is driven mainly by the need of the organisation to conform to external pressures in order to ensure legitimacy (Covaleski \& Dirsmith, 1988; Moll et al., 2006; Meyer \& Rowan, 1977; DiMaggio \& Powell, 1983). However, according to Hannan and Freeman (1977), competitive pressures 
are associated with newly emerging fields and with innovations in established areas. The fundamental premise of the competitive pressure assumes that adopting a particular organisational system is driven mainly by the desire for increased internal efficiency (Etherington \& Richardson, 1994; Tuttle \& Dillard, 2007; Gonzalez et al., 2009). Thus, in exploring an emerging field or innovation in an existing field such as IR, including its assurance practices (Simnett \& Huggins, 2015; Gunarathne and Senaratne, $2017^{4}$ ), it could be imperative to incorporate competitive pressures as well.

Intending to provide a full spectrum of why companies adopt IR voluntarily, this study extends the framing theory by incorporating the isomorphic pressures in the institutional theory. Table I illustrates the application of the theories to achieve the objectives of the study.

Table I: Application of Theories in Model Development

\begin{tabular}{|c|c|c|}
\hline Objective & Theory & Application \\
\hline $\begin{array}{l}\text { The rationale behind obtaining } \\
\text { external IR assurance. }\end{array}$ & $\begin{array}{l}\text { Framing Theory } \\
\text { Institutional } \\
\text { Theory }\end{array}$ & $\begin{array}{l}\text { Diagnostic framing } \\
\text { (identification of problem), } \\
\text { coupled with institutional } \\
\text { and competitive pressures, } \\
\text { is used to identify and } \\
\text { organize different views on } \\
\text { why companies choose to } \\
\text { have their integrated report } \\
\text { disclosures independently } \\
\text { assured. }\end{array}$ \\
\hline $\begin{array}{l}\text { Impacts of external assurance } \\
\text { on internal assurance practices. }\end{array}$ & Framing Theory & $\begin{array}{l}\text { Prognostic framing } \\
\text { (proposition of remedies) is } \\
\text { used in identifying the } \\
\text { impacts of external } \\
\text { assurance on internal } \\
\text { assurance practices. }\end{array}$ \\
\hline $\begin{array}{l}\text { The justification for } \\
\text { modifications made to the } \\
\text { internal assurance practices. }\end{array}$ & Framing Theory & $\begin{array}{l}\text { Motivational framing } \\
\text { (identification of driving } \\
\text { change) is expected to } \\
\text { expose the justification for } \\
\text { modifications made to the } \\
\text { internal assurance practices. }\end{array}$ \\
\hline Implications to the external & Framing Theory & $\begin{array}{l}\text { Motivational framing is } \\
\text { extended to identify the }\end{array}$ \\
\hline
\end{tabular}

${ }^{4}$ Gunarathne and Senaratne (2017) posit IR as a managerial innovation in the corporate reporting space using the diffusion of innovation theory. 
assurance practices.

implications for external

assurance practices.

\section{Source: Author Constructed}

The proposed conceptual model grounded on the two theories is presented in the next section.

\section{Model Development}

The proposed conceptual model of the study is presented in Figure I.

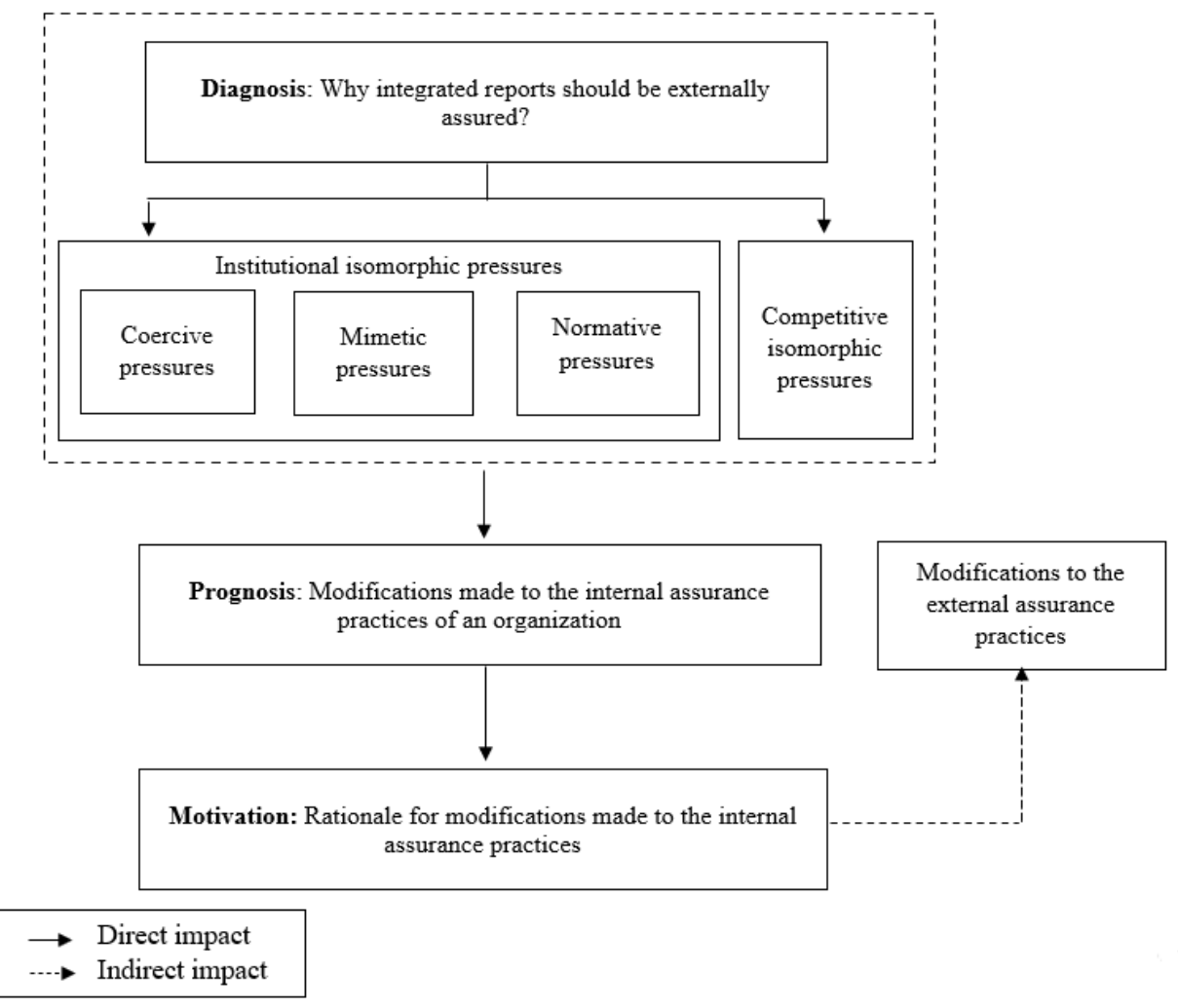

Figure I: Conceptual Model (Source: Author Constructed)

The conceptual model suggests that the companies which tend to assure their integrated reports externally respond to various isomorphic pressures. This indicates that from an institutional- pressures perspective (i.e., coercive, mimetic and normative), some companies would pursue the external assurance of IR as an exercise to ensure legitimacy. Similarly, from a competitive-pressures perspective, companies obtain external assurance to increase internal efficiency. More specifically, since IR is an innovation in the established corporate-reporting field (Simnett \& Huggins, 2015), some companies would adopt the external assurance of IR to enhance the organisation's efficiency. 
The assurance of an integrated report in response to various isomorphic pressures can modify the internal assurance practices addressed through the prognosis framing task. Maroun (2019) finds that external assurance complements the work performed by internal audits. This is especially true in more complex environments where internal audit alone lacks the resources, expertise or independence to test the underlying data and systems. Further, this ensures that the integrated report's information is accurate and provides the organisation with feedback on how to improve its systems. Hence, external assurance supports those charged with governance in an organisation to strengthen its three lines of defence (IIA, 2013). Though the auditor has not expressed an opinion on the fair presentation of the integrated report, because some of the underlying data and controls have been tested, those charged with governance receive comfort from the fact that the content in the report is based on a sound system. In a similar vein, Briem and Wald (2018) suggest that the IR assurance can affect internal processes in terms of the following: coordination between different parts of the organisation, improved systems to capture non-financial indicators and employee training on changing reporting requirements such as IR, all of which provide a holistic representation of value creation (IIRC, 2013; 2021).

As discussed above, prognosis framing suggests that external assurance could improve a company's internal assurance practices (such as internal controls and information systems), provide comfort to those charged with governance and enhance coordination between different parts of the organisation. It further suggests that there can be an underlying rationale that has encouraged implementing such modifications to internal assurance practices, which is exposed through the motivational framing task. The main justification for modifying the internal assurance practices is to enhance the quality of the integrated report, providing more reliable disclosures on non-financial information (Maroun, 2019; Briem \& Wald, 2018; PwC, 2015; Zhou et al., 2017). Thus, it increases the overall usefulness of an integrated report, adding value to the stakeholders. The other primary rationale could be enhanced internal efficiency. The modifications to the internal assurance practices result in better coordination between the different parts of the organisation, better decision-making as a result of the availability of financial and non-financial information through the improved systems, a more skilful employee base through training as well as better control over the resources through improved internal controls (Maroun; Briem \& Wald, 2018).

As reflected in the preceding section, it can be argued that the external assurance on IR could enhance both the usefulness of the information provided to the stakeholders and the efficiency of an organization, but which may also indirectly warrant changes to the existing external assurance practices (as indicated by the dotted arrow in the conceptual model). In this respect, Maroun (2019) found the need to develop additional guidance on the type of information usually included in an integrated report which could be the subject matter of an assurance engagement. Further, it was suggested that accounting and auditing students need to be exposed to different assurance services and reporting frameworks, not only to conventional financial statement audits (Maroun, 2019). Another possibility, currently taking 
shape in South Africa, is coupling the use of existing external audit services with the work of internal audit and the active monitoring of internal control systems by those charged with an organisation's governance to ensure the integrity of the integrated report (IOD, 2016). In the future, auditors may also rely on multidisciplinary teams of experts, supported by continuous audit software and big data analytics to express opinions on the completeness of an integrated report, the methods used to prepare the report and the extent to which it addresses stakeholders' information needs (Maroun, 2017).

The study's proposed model highlights the importance of external assurance to enhance the reliability of information presented in an integrated report. This has farreaching implications for developments in both internal and external assurance practices, standards and related technologies. On this premise, the final section of the study presents future directions and applications of this model.

\section{Future Directions and Applications}

The study proposes a conceptual model based on the framing and institutional theories to explore why companies externally assure their integrated reports, the impact of this action on internal assurance practices, the rationale for modifications made to the internal assurance practices and implications for the external assurance practices. This study contributes to knowledge in two ways. First, this is one of the first studies to combine the framing and institutional theories to explore IR assurance and its implications on organisations. Second, this study extends the current discussion on IR assurance by introducing the impact of external assurance of IR on internal assurance practices, which are required to support integrated thinking and reporting.

This proposed model offers several avenues for researchers to explore IR assurance practices. First, a future study can test this model empirically in its totality or partially in different contexts where the adoption of IR is voluntary (i.e., Sri Lanka) or mandatory (i.e., South Africa). Such a study would facilitate the identification of how the different institutional country settings could impact IR assurance. Second, the model can be extended to reflect the implications of external assurance of IR on business and reporting practices. As of now, the model only assumes changes to the internal and external controls and assurance practices. However, since external assurance has implications for broader organisational and reporting (such as IR) practices, changes in these practices can also be an interesting avenue to explore. Third, the researchers can also modify this model to suit different circumstances while keeping its core premises. For instance, this model utilises a social-based theory, the institutional framing, to explore the factors driving external assurance. However, future studies can use other theories, such as contingency or resourcebased theory, to provide a more internal-oriented focus of the motivations for IR assurance.

This study also carries certain practical implications. First, this model could be used to justify the importance of obtaining external assurance of IR by the regulators of a country, such as the Securities and Exchange Commission and the Stock Exchange. This study would also encourage professional accounting bodies to promote the 
external assurance of IR. Also, through the model's emphasis on the implications of external assurance practices, auditors can be motivated to think of innovative ways to assure the integrated report, such as relying on multidisciplinary teams or using audit software and big data analytics. Further, this model could persuade the accounting academics to incorporate the assurance of IR and its implications into their course modules along with contemporary developments in corporate reporting.

This research was supported by the Accelerating Higher Education Expansion and Development Operation of the Ministry of Higher Education, Sri Lanka, funded by the World Bank.

\section{References}

AccountAbility (AA). (2018). AA1000 Accountability Principles Standard 2018, Available at www.accountability.org (accessed 20 March 2021).

Adams, S., \& Simnett, R. (2011). Integrated reporting: An opportunity for Australia's not-for profit $\quad$ sector, Australian $\quad$ Accounting $\quad$ Review, $\quad 21(3)$, 292-301.doi:10.1111/j.18352561.2011.00143.x

Adams, C.A. (2015). The International Integrated Reporting Council: a call to action, Critical Perspectives on Accounting, 27, 23-28. doi.org/10.1016/j.cpa.2014.07.001

Ascui, F., \& Lovell, H. (2011). As frames collide: making sense of carbon accounting,

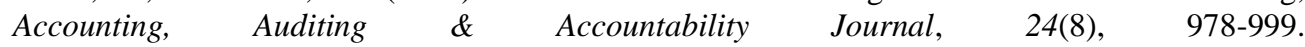
doi:10.1108/09513571111184724

Bay, C. (2011). Framing financial responsibility: an analysis of the limitations of accounting, Critical Perspectives on Accounting, 22(6), 593-607. doi:10.1016/j.cpa.2011.03.001

Benford, R.D., \& Snow, D.A. (2000). Framing processes and social movements: an overview and assessment, Annual Review of Sociology, 26(1), 611-639. doi:10.2307/223459

Briem C.R., \& Wald A. (2018). Implementing third-party assurance in integrated reporting Companies' motivation and auditors' role, Accounting, Auditing \& Accountability Journal, 31(5), 1461-1485. doi:10.1108/AAAJ-03-2016-2447

Busco, C., Frigo, M.L., Riccaboni, A. \& Quattrone, P. (2013). Integrated reporting concepts and cases that redefine corporate accountability, Springer, Cham.

Camodeca, R., Almici, A., \& Sagliaschi, U. (2018). Sustainability disclosure in integrated reporting: does it matter to investors? A cheap talk approach, Sustainability Journal, 10(12), 4393. doi:10.3390/su10124393

Chen, S. \& Bouvain, P. (2009). Is corporate responsibility converging? A comparison of corporate responsibility reporting in the USA, UK, Australia, and Germany, Journal of Business Ethics, 87(1), 299-317. doi:10.1007/s10551-008-9794-0

Cheng, M., Green, W., Conradie, P., Konishi, N., \& Romi, A. (2014). The international integrated reporting framework: key issues and future research opportunities, Journal of International Financial Management \& Accounting, 25(1), 90-119. doi:10.1111/jifm.12015

Cooray, T., Senaratne, S., Gunarathne, A.D.N, Herath, R., \& Samudrage, D. (2020). Does integrated reporting enhance the value relevance of information? Evidence from Sri Lanka, Sustainability Journal, 12(19), 8183. doi.org/10.3390/su12198183

Cooray, T., Senaratne, S., Gunarathne, N., Herath, R. \& Samudrage, D.N. (2021). Adoption of integrated reporting in Sri Lanka: coverage and trend, Journal of Financial Reporting and Accounting, doi.org/10.1108/JFRA-04-2020-0116. 
Corrado, M., Demartini, P., \& Dumay, J. (2019). Assurance on integrated reporting: A critical perspective, CSR, Sustainability, Ethics \& Governance, 199-217. doi:10.1007/978-3-030-017194_11

Covaleski, M. A., \& Dirsmith, M. W. (1988). An institutional Perspective on the rise, social transformation, and fall of a university budget category, Administrative Science Quarterly, 33(4), 562-587. doi:10.2307/2392644

Deegan, C, Cooper, B and Shelly, M (2006), An investigation of TBL report assurance statements: UK and European evidence, Managerial Auditing Journal, 21(4), 329-371. doi:10.1108/02686900610661388

de Villiers, C., Pei-Chi, K.H. \& Maroun, W. (2017). Developing a conceptual model of influences around integrated reporting, new insights and directions for future research, Meditari Accountancy Research, 25(4), 450-460. doi:10.1108/MEDAR-07-2017-0183

DiMaggio, P.J., \& Powell, W.W. (1983). The iron cage revisited: institutional isomorphism and collective rationality in organisational fields, American Sociological Review, 48(2), 147-160. doi.org/10.2307/2095101

Dragu, I. \& Tiron-Tudor, A. (2013). The integrated reporting initiative from an institutional perspective: emergent factors, Procedia - Social and Behavioral Sciences, 92, 275-279. doi:10.1016/j.sbspro.2013.08.672

Dumay, J., Bernardi, C., Guthrie, J., \& Demartini, P. (2016). Integrated reporting: a structured literature review, In Accounting Forum, 40(3), 166-185. doi:10.1016/j.accfor.2016.06.001

Du Toit, E. (2017) The readability of integrated reports, Meditari Accountancy Research, 25(4), 629-653. doi/10.1108/MEDAR-07-2017-0165.

Eccles, R.G. \& Krzus, M.P. (2010). One report: integrated reporting for a sustainable strategy, Wiley, New Jersey.

Etherington, L. D., \& Richardson, A. J. (1994). Institutional pressures on university accounting education in Canada, Contemporary Accounting Research, 10(S1), 141-162. doi.org/10.1111/j.1911-3846.1994.tb00426.x

Fortanier, F., Kolk, A., \& Pinkse, J. (2011). Harmonisation in CSR reporting: MNEs and global CSR standards, Management International Review,51(5), 665-696. doi:10.2307/41411001

Global Reporting Initiative (GRI), (2020), GRI Sustainability Reporting Standards, Available at www.globalreporting.org (accessed 22 March 2021)

González, J. M. G., Arquero Montaño, J. L., \& Hassall, T. (2009). Pressures and resistance to the introduction of skills in business administration and accounting education in Spain: A new institutional theory analysis. Journal of Vocational Education and Training, 61(1), 85-102. doi.org/10.1080/13636820902820071

Goicoechea, E., Gómez-Bezares, F., \& Ugarte,J.U. (2019). Integrated reporting assurance: Perceptions of auditors and users in Spain, Sustainability Journal, 11, 713-732. doi:10.3390/su11030713

Gunarathne, N., \& Senaratne, S. (2017). Diffusion of integrated reporting in an emerging South Asian (SAARC) nation, Managerial Auditing Journal, 32(4/5), 524-548. doi:10.1108/MAJ-012016-1309

Hannan, M.T., and J.H. Freeman. (1977). The population ecology of organisations, American Journal of Sociology, 82, 929-964. doi.org/10.1086/226424 
Herath, R., Senaratne, S., \& Gunarathne, N. (2021). Integrated thinking, orchestration of the six capitals and value creation, Meditari Accountancy Research, doi.org/10.1108/MEDAR-01-20200676.

Huggins, A., Simnett, R., \& Hargovan, A. (2015), Integrated reporting and directors' concerns about personal liability exposure: law reform options, Company and Securities Law Journal, 33(3), 176-195.

Institute of Internal Auditors. (2013). The three lines of defense in effective risk management and control, Available at: https://na.theiia.org. (accessed 25 March 2021)

International Federation of Accountants. (2014). International framework for assurance engagements, Handbook of international quality control, Available at: www.iaasb.org. (accessed 25 March 2021)

IIRC. (2011). Towards Integrated Reporting: Communicating Value in the 21st Century, IIRC, available at: http://integratedreporting.org/wp-content/ uploads/2011/09/IR-Discussion-Paper2011_spreads.pdf (accessed 15 February 2021)

IIRC. (2013). The international framework: integrated reporting, IIRC, available at: www.theiirc.org/wpcontent/uploads/2013/12/13-12-08-TheInternational-IR -Framework-2-1.pdf (accessed 20 February 2021)

IIRC. (2021). The international framework: integrated reporting, IIRC, available at: www.theiirc.org/wpcontent/uploads/2013/12/13-12-08-TheInternational-IR -Framework-2-1.pdf (accessed 20 February 2021)

IIRC. (2014). Assurance on IR: an exploration of issues, IIRC, available at: www.theiirc.org/wpcontent/uploads/2014/07/Assurance-on-IR-an-exploration-of-issues.pdf (accessed 25 February 2021)

IOD. (2016). King IV report on corporate governance in South Africa, LexisNexis South Africa, Johannesburg.

Integrated Reporting Committee of South Africa. (2014). Preparing an integrated report, available at: http://integratedreportingsa.org/ircsa/wp-content /uploads/ 2017/05/ IRCSA_ Starters Guide.pdf (accessed 28 May 2021).

Kaplan, S. (2008). Framing contests: strategy making under uncertainty, Organization Science, 19(5), 729-752. doi:10.2307/25146214

KPMG. (2017). The road ahead:The KPMG Survey of Corporate Responsibility Reporting 2017, KPMG, Available: https: // assets. kpmg. com/ content/ dam /kpmg/xx/pdf/2017/10/kpmgsurvey-of-corporate-responsibility-reporting-2017.pdf

Lasmin (2011). An institutional perspective on international financial reporting standards adoption in developing countries, Academy of Accounting \& Financial Studies Journal, 15(2), 61-71.

Maroun, W. (2017). Assuring the integrated report: insights and recommendations from auditors and preparer, The British Accounting Review, 49(3), 329-346. doi:10.1016/j.bar.2017.03.00 3

Maroun, W. (2019). Exploring the rationale for integrated report assurance, Accounting, Auditing \& Accountability Journal, 32(6), 1826-1854. doi/10.1108/AAAJ-04-2018-3463

Martínez-Ferrero, J., \& García-Sánchez, I.M. (2017). Coercive, normative and mimetic isomorphism as determinants of the voluntary assurance of sustainability reports, International Business Review, 26(1), 102-118. doi.org/10.1016/j.ibusrev.2016.05.009

Meyer, J. W., \& Rowan, B. (1977). Institutionalised organisations: Formal structure as myth and ceremony, American Journal of Sociology, 83(2), 340-63. doi.org/10.1086/226550 
Mizruci, M.S. \& Fren, L. C. (1999). The social construction of organisational knowledge: A study of the uses of coercive, mimetic, and normative isomorphism, Administrative Science Quarterly, 44(4), 653-683 doi.org/10.2307/2667051

Moll, J., Burns, J., \& Major, M. (2006). Institutional theory, methodological issues in accounting research: Theories and methods, London: Spiramus

Nicolo, G., Zanellato, G. \& Tiron-Tudor, A. (2020). Integrated reporting and European stateowned enterprises: a disclosure analysis pre and post", Sustainability Journal, 12(5),1908-2014. doi. org /10.3390/su12051908

Oliver, C. (1991). Strategic responses to institutional processes, Academy of Management Review, 16(1), 145-179. doi.org/10.5465/amr.1991.4279002

Prinsloo, A. and Maroun, W. (2020). Drivers of combined assurance in a sustainable development context: Evidence from integrated reports, Business Strategy and the Environment, 29(8), 3702-3719. doi.org/10.1002/bse.2606

PwC. (2015). Integrated reporting where to next?, available at: www.pwc.co.za/en/assets/pdf/ integrated-reporting-survey-2015.pdf

Rinaldi, L., Unerman, J., \& de Villiers, C. (2018). Evaluating the integrated reporting journey: insights, gaps and agendas for future research, Accounting, Auditing \& Accountability Journal, 31(5), 1294-1318. doi/10.1108/AAAJ-04-2018-3446

Robertson, F. A., \& Samy, M. (2015). Factors affecting the diffusion of integrated reporting - a UK FTSE 100 perspective. Sustainability Accounting, Management and Policy Journal, 6(2), 190-223. doi/10.1108/SAMPJ-07-2014-0044

Roussy, M., \& Brivot, M. (2016). Internal audit quality: a polysemous notion?, Accounting, Auditing \& Accountability Journal, 29(5), 714-738. doi/10.1108/AAAJ-10-2014-1843

Snow, D.A., Rochford, E.B., Worden, S.K. \& Benford, R.D. (1986). Frame alignment processes, micromobilization, and movement participation, American Sociological Review, 51(4), 464-481. doi.org/10.2307/2095581

Simnett, R., \& Huggins, A.L. (2015). Integrated reporting and assurance: where can research add value?, Sustainability Accounting, Management and Policy Journal, 6(1), 29-53. doi/10. 1108 /SAMPJ-09-2014-0053

Stubbs, W., \& Higgins, C. (2014). Integrated reporting and internal mechanisms of change, Accounting Auditing \& Accountability Journal, 27(7), 1068-1089. doi.org/10.1108/AAAJ-032013-1279

Tlili, M., Ben Othman, H. \& Hussainey, K. (2019). Does integrated reporting enhance the value relevance of organisational capital? Evidence from the South African context, Journal of Intellectual Capital, 20(5), 642-661. doi/10.1108/JIC-02-2019-0034

Tuttle, B. \& Dillard, J. (2007). Beyond competition: Institutional isomorphism in U.S. accounting research, Accounting Horizons, 21(4), 387-409. doi.org/10.2308/acch.2007.21.4.387

Vaz, N., Fernandez-Feijoo, B., \& Ruiz, S. (2016). Integrated reporting: an international overview, Business Ethics: A European Review, 25(4), 577-591. doi.org/10.1111/beer.12125 